\title{
MACHADO DE ASSIS E A APROVAÇÃO INCONDICIONAL DA VIDA: O TRÁGICO EM "PAI CONTRA MÃE"
}

\author{
LEANDRO SANTOS RESENDE \\ Universidade de São Paulo \\ São Paulo, São Paulo, Brasil
}

Resumo: O presente texto se baseia na linha interpretativa desenvolvida por Rogério de Almeida que define Machado de Assis como um autor alinhado à filosofia trágica. Objetiva-se, por meio dessa fundamentação, analisar o conto "Pai contra mãe" para mostrar aquilo que parece ser a lição mais importante a ser aprendida, a saber, a aprovação incondicional da vida. Consideramos que a leitura desse conto exemplifica a seguinte distinção: por um lado, temos todas as concepções não trágicas, as quais se fundamentam por uma intenção que estabelece uma ordenação e sentido à existência; por outro lado, temos a intenção trágica que se contrapõe às demais e nada estabelece sobre o sentido do ser, porque nada há além do acaso como determinação dos acontecimentos.

Palavras-chave: Machado de Assis; filosofia trágica; aprovação incondicional da vida

\section{MACHADO DE ASSIS AND THE UNCONDITIONAL APPROVAL OF LIFE: THE TRAGIC IN "FATHER VERSUS MOTHER"}

Abstract: This paper is based on the interpretation developed by Rogério de Almeida, who defines Machado de Assis as an author aligned with tragic philosophy. The purpose of this paper is to analyze the short story "Father Versus Mother" to show what appears to be the most important lesson to be learned, namely, the unconditional approval of life. We believe that the reading of this short story exemplifies the following distinction: on the one hand, we have all the non-tragic conceptions, which are based on an intention that establishes an ordering and meaning to life; on the other hand, we have the tragic intention that is opposed to the others and establishes nothing about the meaning of being, because there is nothing other than chance determining the events.

Keywords: Machado de Assis; tragic philosophy; unconditional approval of life 
Aquele que não sabe dispor sua vontade nas coisas quer ao menos atribuir-lhes um sentido: o que o faz acreditar que já existe uma vontade nelas (Princípio da "fé").

Friedrich Nietzsche

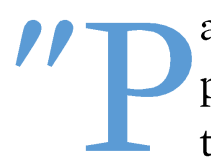
ai contra mãe", publicado em 1906 em Relíquias de casa velha, é um pequeno conto que expressa o impasse em que muitos, se não todos, se veem quando diante do trágico e da necessidade de escolha, assunto de que trataremos no decorrer deste ensaio. Não se trata tão somente de escolher entre o certo e o errado em dada circunstância: trata-se de uma escolha que nenhuma formação escolar, talvez nenhuma instância formativa, seja capaz de preparar metodologicamente, a saber, aprovar a vida acima de todas as coisas. Nesse contexto, Machado de Assis pode ser apresentado como um autor estratégico para pensar algumas questões cruciais do percurso educacional, de uma sabedoria trágica, que fogem do registro normativo. Em especial, o pensamento trágico, que tem por objeto justamente aquilo de que não se pode fugir completamente, mas que se tenta calar e depois ignorar. Nos textos de Machado de Assis, à revelia das personagens, as circunstâncias trágicas surgem para lembrar o que se tentou esquecer: o acaso ${ }^{1}$ que determina os acontecimentos. Vemos recorrentemente a dificuldade de aprovação do que parece não fazer sentido, do que parece injusto, do que parece desordem. Entretanto, o acaso sempre aparece para desespero de muitos, para aqueles de "ideias fixas", para aqueles que filosofam sobre como o mundo deveria ser. Esta é a lição que podemos depreender repetidamente em suas obras, uma fria e crua expressão do que todos percebem de algum modo, mas tentam fingir que não sabem ou que não existe.

Não faremos um recorte maior que o supracitado conto, porque este, mesmo diminuto, já ilumina suficientemente a questão que nos propomos apresentar e o posicionamento que procuraremos fundamentar. Não temos a intenção, obviamente, de pôr fim às várias considerações possíveis sobre a contribuição da literatura machadiana para a formação escolar e, em acepção mais ampla, para a Educação. Temos interesse somente em mostrar que, mesmo em um conto de menor extensão, o trágico aparece tão claramente quanto em obras mais extensas, entre as quais poderíamos citar, por exemplo,

\footnotetext{
1 “Acaso" entendido a partir do termo em francês hasard, isto é, arriscado, temerário, perigoso; a outra origem, que é insuficiente, advém do latim casus, derivação da ideia de queda (cadere).
} 
Memórias póstumas de Brás Cubas, Quincas Borba e Dom Casmurro, a trilogia machadiana.

Obviamente, é dispensável lembrar a enorme gama de enfoques de estudos da obra de Machado de Assis. Antes de emitir qualquer juízo sobre as várias possibilidades de leitura e as implicações para outras áreas, enfatizamos a importância do debate e o valorizamos. Não obstante, o enfoque de que aqui nos valemos é uma recente proposta de leitura sugerida por Rogério de Almeida, que estabelece aproximações da obra machadiana com o pensamento trágico.

A filosofia trágica tem como fundador Friedrich Nietzsche, o qual se autointitula o primeiro filósofo trágico para "que o espírito científico deixe de ser ilimitado e sua pretensão a uma validade universal seja aniquilada". ${ }^{2}$ Clément Rosset se situa como porta-voz e continuador dessa vertente. Entendemos que as bases da filosofia trágica se encontram nesses autores, mas isto não significa que o pensamento trágico não tenha figuras de um passado mais remoto. Tal é o caso de Lucrécio, Pascal e Montaigne, por exemplo ainda que não se possa afirmar que esses filósofos tenham inaugurado uma filosofia trágica.

Epistemologicamente o pensamento trágico é indefinido. Surge em decorrência da percepção de que o conhecimento pode ser explicado de várias formas, defendido por vários pontos de vista sobre o mundo, dos quais a história é repleta de exemplos. O pensador trágico não defende uma epistemologia que considera a certa, mas podemos dizer que para ele basta a perspectiva situacional, ou seja, aquela convencionada entre os produtores de conhecimento, aqueles que detêm os métodos mais aceitos pela comunidade científica e acadêmica. Isso não significa a admissão da ciência como critério para a verdade, para atingir as essências das coisas, afinal também a ciência em si mesma, assim como a mitologia e a filosofia, é objeto de crença para orientar o olhar e organizar o modo como pensamos a realidade - em outras palavras, também é objeto de ilusão. Se a epistemologia "situacional" é a que parece a melhor dentre as várias possíveis, o pensador trágico só o diz por mera conveniência, pois nada há para acreditar. Clément Rosset $^{3}$ afirma que "uma única fórmula basta para caracterizar o pensamento trágico: $a$ impossibilidade de crer que possa haver crença".

Com base nessa observação, justificamos o ponto de partida de nossas considerações: a epistemologia e sua negação. Contudo, os homens parecem

${ }^{2}$ MACHADO, Zaratustra, tragédia nietzschiana, p. 13.

${ }^{3}$ ROSSET, Lógica do pior, p. 39. 
crer com todas as forças em teorias e ideais tentando substituir aquilo que não querem ver: o trágico. Mas o que é o objeto de crença, se não uma invenção, uma criação que corresponde a nada?

Fora das pretensões de formular a epistemologia que melhor traduza a aquisição e a produção de conhecimento e uma racionalização do mundo, entendemos que o pensamento trágico emerge de um despertar cético, de uma visão do conflito das doutrinas e sobretudo dos dogmas filosóficos. Desse modo, não há uma posição a ser tomada em meio ao relativismo das perspectivas sobre o mundo, porque não há nem no ceticismo nem no pensamento trágico uma teoria fundamentada sobre um ponto de vista ordenador da realidade. Essa característica permite uma distinção singular entre as filosofias não trágicas e as filosofias trágicas:

Se se chama filosofia um corpo de considerações que sejam um objeto de adesão sem reticências nem segundas intenções, dir-se-á que as únicas filosofias existentes são as trágicas. Consequência aparentemente paradoxal das premissas das quais procede o pensamento trágico: não há filosofias não trágicas. Sem dúvida existe Platão, Kant, Hegel; mas, nem as "ideias" de Platão, nem aquelas de Kant, nem o "espírito absoluto" de Hegel existem - na medida em que estes definem, para o pensador trágico, não um conteúdo, mas um modo de crença. Construções suntuosas, feitas de nadas: seus elementos de base sendo indefiníveis. Se não pode haver adesão aos temas não trágicos, é que não há, para falar propriamente, temas não trágicos: somente direção de intenção (não trágica). Assim o não trágico é aquilo que se diz sem conseguir-se pensar, e o trágico aquilo que se pensa sem, geralmente, aceitar-se dizer. ${ }^{4}$

Um exemplo disso, do que se pensa e não se diz, é contrariado justamente pelo protagonista do conto quando abençoa a fuga da escrava, que aborta como consequência da fuga: diferente de um filósofo orientado por um modo de crença, Cândido Neves simplesmente não se importa. O sentido orientado pela crença é o que define a distinção citada, a adesão implica uma intenção que nega o nada de sentido que existe, ou seja, a vida aqui e agora, crua. ${ }^{5}$ A criação de um conteúdo conceitual para além da realidade é sintoma da agonia em tentar organizar a realidade face ao caos existente e sua falta de sentido. Inevitavelmente decorrem da intenção não trágica modelos

\footnotetext{
${ }^{4}$ Idem, p. 41.

${ }^{5}$ Clément Rosset desenvolve a noção de crueldade em um pequeno livro. Cf. ROSSET, Princípio de crueldade.
} 
metafísicos, epistemológicos, morais e políticos. Temos, assim, o terreno para as disputas filosóficas em busca da verdade, isto é, em busca de um irrefutável modelo discursivo de ordenação da desordem "aparente".

Não obstante, em meio a essa empresa, esconde-se ainda uma "esperança secreta”, a saber, a crença de que a partir da inteligência é possível alcançar a felicidade. Trata-se de um "fantasma cujo otimismo é ao mesmo tempo de natureza ontológica e teleológica. [...] Nessas perspectivas, o exercício da filosofia recobre uma tarefa séria e tranquilizadora: um ato simultaneamente construtor e salvador". ${ }^{6}$ Construtor porque concebe uma ordenação dos seres e do próprio ser, salvador porque o fim da ordenação implica a melhora das condições da vida humana.

Neste ponto podemos ver uma forte evidência para afirmar que o pensamento trágico emerge de um despertar cético, pois o ceticismo não aposta na construção de um discurso pretensamente verdadeiro sobre a natureza ou a realidade para alcançar a tranquilidade (ataraxia). Sua "tarefa séria e tranquilizadora" repousa sobre a suspensão do juízo (ephoké) que abre mão de qualquer afirmação sobre a natureza das coisas.

Várias podem ser as razões para se chegar ao ceticismo, ${ }^{7}$ a suspeita alimentada pela intuição do trágico parece ser uma delas, pois a percepção da relatividade dos princípios e valores que fundamentam os discursos inevitavelmente implica a percepção de que a verdade não tem um critério de decisão sobre a verdadeira natureza do real. Resta então suspender o juízo, adiar uma resposta, mostrar a dissonância (diaphonia) entre os discursos anulando-os quando em disputa, ${ }^{8}$ evidenciando, assim, a falta de critério para estabelecer a verdade.

Os discursos filosófico-dogmático-interpretativos de intenção não trágica estabelecem modos de crenças, criam ideias e mundos para além deste, um nada metafísico que faz confundir a criação do pensamento com a própria realidade. Em outras palavras, "a metafísica é incapaz de expressar o mundo, em sua tragicidade, pela prevalência que concede à verdade em detrimento da ilusão". ${ }^{9}$ Esta é a razão para Rosset separar a filosofia em intenção trágica e não trágica: o não trágico desaprova a crua realidade dos acontecimentos e a impossibilidade da crença, ele nega substituindo-as por um corpo de considerações com objetos inexistentes; o trágico, por sua vez, aprova a vida com tudo o que ela tem de cruel, não cria interpretações para legitimar uma

${ }^{6}$ ROSSET, Lógica do pior, p. 14.

${ }^{7}$ Não iremos aqui investigar isso sistematicamente, por motivos óbvios.

${ }^{8}$ Trata-se do método cético da antinomia (isosthéneia).

${ }^{9}$ MACHADO, Zaratustra, tragédia nietzschiana, p. 12. 
ordem que estabelece o certo e o errado, o bem e o mal e o que aparece (phainomenon).

Portanto, epistemologicamente, é indiferente a adoção de uma ou outra teoria sobre o modo como conhecemos, pois isso não muda o sentido de existência das coisas e não nos permite compreender o que elas são de verdade, na essência, metafisicamente. Tudo que é da ordem do pensável e do designável é essencialmente desprovido de sentido, determinado pelo acaso, convenção em meio ao caos em que nos encontramos. A tentativa de ordenação do olhar e de justificação do sentido da vida no fim das contas exprime somente a angústia do homem que sabe de onde veio e para onde vai:

Nada pode garantir a permanência de algo que, como expressou Schopenhauer, desperta com o nascimento e se apaga com a morte. Portanto, a consciência que atina para o nada que era antes de nascer, embora o mundo fosse, e para o nada que a espera, ainda que o mundo permaneça, tem a difícil escolha de aprovar uma existência sem princípio ou finalidade que não de ordem circunstancial (escolha trágica), ou, não suportando tal visão, crer em algo que justifique a existência (escolha não trágica). ${ }^{10}$

Resta então a escolha pela aprovação da existência sem princípio e finalidade: passo que o cético hesita em dar, porque ainda tem em vista um fim, a salvação, mesmo que não tenha nada mais a construir e não acredite em um mundo além deste. Uma vez suspenso o juízo (epokhé), o cético se cala (aphasia), parece guardar a esperança de permanecer imperturbável (ataraxia) e indiferente (adiforia), esta é a sua salvação. O filósofo trágico, por sua vez, procura trazer à fala as implicações da impossibilidade de crer que possa haver crença. Neste ponto o cético fica no meio do caminho, pois sua tarefa se limita somente a livrar os homens do dogmatismo; porém, em face da vida se resigna a viver uma vida comum, ${ }^{11}$ sem ambições e indiferente aos acontecimentos. Em vista disso, podemos precisar que Cândido Neves não é cético, porque não é indiferente, ele afirma sua vontade e sofre emocionalmente com a perturbação de entregar seu filho à roda dos enjeitados.

\footnotetext{
${ }^{10}$ ALMEIDA, Aprendizagem de desaprender: Machado de Assis e a pedagogia da escolha, p. 1004.

${ }^{11}$ Oswaldo Porchat Pereira é um dos principais nomes do neopirronismo que procura resgatar a filosofia cética de Sexto Empírico e levantar razões para viver uma vida comum, já que a tarefa da filosofia de busca da verdade se mostrou falida. Cf. PORCHAT PEREIRA, Rumo ao ceticismo.
} 
Portanto, os céticos não são ainda filósofos trágicos porque adiam a aprovação da vida, escolhem apenas ficar "imperturbáveis". O filósofo trágico, por sua vez, mesmo consciente de que nada há além da vida comum para viver, escolhe vivê-la não com resignação, mas com aprovação incondicional. Temos isso tanto no conto quanto na escolha. "A questão central, portanto, seria essa vontade de viver, essa fúria, essa adesão à vida, essa alegria existencial que, mesmo diante de uma realidade desagradável, não cessa de se manifestar."12

Não obstante, é preciso sublinhar que a dúvida que inspira a escolha trágica não é privilégio só de quem adota conscientemente a via cética, pelo contrário:

A desconfiança é, tanto e ao mesmo título que o bom senso, um componente universal e inerradicável do pensamento humano. A precipitação, ou o otimismo dos filósofos, é frequentemente subestimarlhe a potência. Victor Brochard, em seu estudo, outrora exaltado por Nietzsche, sobre os Céticos gregos, tinha já sublinhado o fato: o ceticismo não representa, como tentam fazer crer numerosos filósofos, a voz de alguns pensadores raros e estranhos, de pessimismo exacerbado, mas primeiramente e antes de tudo a voz popular, aquela do senso comum. ${ }^{13}$

Por meio da dúvida o trágico aparece tanto aos pensadores céticos quanto aos homens comuns. Mas àqueles que firmam crença em fundamentos explicativos de ordenação da existência o acaso inflige os golpes mais duros. Ocorre que a maioria dos homens oscila entre uma coisa e outra: o trágico raramente é admitido em sua totalidade. Assim, os homens parecem transitar entre a "paranoia da interpretação" que nega o acaso e o "senso trágico" que o afirma:

Talvez não haja outra forma de lógica além da paranoia e da filosofia trágica. Todo homem dito "normal" se diferencia, aliás, do paranoico caracterizado, nisto que ele é um composto de paranoia e de intuição trágica: ora intérprete, ora afirmador do acaso. ${ }^{14}$

Clément Rosset insiste na consideração sobre o acaso porque com isso a filosofia antitrágica não consegue lidar: "As referências para pensar o não trágico - ideologia, metafísica, religião etc. - partem da crença em algo que,

12 ALMEIDA, O imaginário trágico de Machado de Assis: elementos para uma pedagogia da escolha, p. 205.

${ }^{13}$ ROSSET, Lógica do pior, p. 38.

14 Idem, p. 28. 
por definição, não existe, é nada". ${ }^{15}$ Resta, então, o acaso que é indefinível. Metaforicamente podemos pensar que o acaso tal como a filosofia trágica o concebe é como um jogo de azar em que o jogador ganha ou perde passivamente, sem poder controlar seu destino. Aprovar o acaso é aceitar jogar mesmo sem poder evitar os reveses. ${ }^{16}$ De outro modo, podemos dizer que aprovar o acaso é como escolher viajar de avião. Estar em um avião sem ter acesso à cabine de controle é deixar a vida à própria sorte, estar passivo diante de qualquer circunstância, inclusive de eventuais fatalidades. Podemos aprovar a viagem, mesmo sem saber para onde estamos indo, ou desistir dela, o que neste caso podemos configurar como o suicídio, ou a crença em nada. Conclui-se que não controlamos o sentido da vida e somos carregados pelos ditames do acaso.

No decurso da vida, sempre buscamos justificativas para os acontecimentos e tentamos legitimar um ponto de vista sobre o mundo. Os filósofos são mais bem-sucedidos nessa empreitada, então para estes é mais difícil largar suas muletas conceituais para novamente ver o mundo sem paranoia. O homem comum, por sua vez, ainda que oscile entre paranoia e intuição trágica, se situa mais próximo de uma aprovação da vida. Assim, vemos que o trágico é mais comum do que as filosofias antitrágicas nos fazem pensar e, igualmente, vemos que estas apenas superficialmente impregnam os pensamentos populares.

Os pontos de vista populares sobre o mundo são de maneira geral centrados sobre ideias de desordem, de acaso, de absurdidade, inerentes a toda existência, que a expressão "é a vida" resume em todas as línguas e em todas as épocas; em contrapartida, a ideia de que o mundo está submetido a uma qualquer "razão" ou ordem não é o apanágio senão de um pequeníssimo número de homens, filósofos, cientistas, teólogos, cuja cegueira não é a de se crerem autorizados em afirmarem uma ordem, mas antes de pensar que esta afirmação tem uma influência profunda nos pontos de vista do "popular". ${ }^{17}$

O que nos resta, então, se não aprovar o acaso? O que nos resta dizer, se não "é a vida"?

\footnotetext{
${ }^{15}$ ALMEIDA, Aprendizagem de desaprender: Machado de Assis e a pedagogia da escolha, p. 1004.

${ }^{16} \mathrm{Na}$ Lógica do pior, p. 84-90, Rosset desenvolve quatro diferentes tipos de acaso, a saber: 1) noção de sorte; 2) noção de encontro; 3) noção de contingência; 4) noção de acaso. Lembrando que este último tem origem na acepção francesa de hasard e é a ele que Rosset se refere para caracterizar o trágico.

${ }^{17}$ ROSSET, Lógica do pior, p. 34.
} 
Engana-se quem pensa que a expressão "é a vida" significa a síntese de uma visão pessimista sobre o mundo. Não é difícil ver intérpretes afirmarem que Machado de Assis bebe da fonte do pessimismo. "Este é o maior paradoxo de sua obra e também a razão do fascínio misterioso e inexplicável que sua literatura continua exercendo: a pior realidade por ele imaginada vem sempre acompanhada de uma alegria estética arrebatadora."18

O pessimismo se caracteriza para Rosset como uma atitude negativa oriunda da filosofia antitrágica que espera do mundo uma ordem e dos acontecimentos recompensas morais. Ora, isso é justamente o que não vemos na obra machadiana; se por vezes alguns personagens se queixam de sua sorte e entendem que a ordenação do mundo é má e sem perspectiva de melhora, é por mero capricho de seus pensamentos.

Enquanto o filósofo otimista sistematiza um corpo teórico para cumprir aquela tarefa séria e tranquilizadora de construção e salvação, o pessimista reage negativamente queixando-se das dores de ver esta tarefa sempre falhar. "O pessimista fala após ter visto; o terrorista trágico fala para dizer a impossibilidade de ver."19

O pessimismo nasce de um sentido, após uma ordem criada, que por fim se mostra insatisfatória. Conclui-se então que o que existe é a "pior das combinações compatíveis com a existência". ${ }^{20}$ Para o pessimista o mundo tem uma ordenação que é má - ele é um todo reunido, mas mal reunido. É a filosofia que não tem perspectiva de melhora.

Com efeito, é justamente em face da reação pessimista diante da frustração que o filósofo trágico direciona sua intenção terrorista: "Nietzsche declara, terminando a Genealogia da moral, que 'o homem prefere ainda ter vontade do nada, que nada querer'. Ou seja: mais vale afirmar a dor do que não afirmar nada". ${ }^{21}$ Eis o pior do trágico que difere do pior do pessimista: "o pior pessimista designa uma lógica do mundo, o pior trágico, uma lógica de pensamento (descobrindo-se incapaz de pensar um mundo)". ${ }^{22}$

Quem lê a obra machadiana e espera uma lógica do mundo vê frustrada sua expectativa. Isto parece explicar as várias diretivas ao leitor em suas obras. Machado de Assis parece desconfiar de que esperam de seus textos uma narrativa fundamentada por uma lógica do mundo. Mas ao invés de uma lógica, na obra machadiana temos as convenções:

\footnotetext{
${ }^{18}$ ALMEIDA, O imaginário trágico de Machado de Assis: elementos para uma pedagogia da escolha, p. 79.

${ }^{19}$ ROSSET, Lógica do pior, p. 20.

${ }^{20}$ Ibidem.

${ }^{21}$ Idem, p. 25-26.

22 Idem, p. 20.
} 
Para se compreender o que pode ser chamado de filosofia na obra de Machado de Assis, é preciso estabelecer os extremos desse movimento pendular: de um lado, ausência total de sentido, existência desprovida de razão, eterna surdez; de outro, o homem jogando com as convenções, agarrando-se ao desejo de conservação, atribuindo sentido de acordo com a conveniência. ${ }^{23}$

Não é outra coisa o que acontece com o protagonista de "Pai contra mãe"; ele simplesmente joga com as convenções, representa uma "posição diante da vida: ingenuidade, pureza, inocência", ${ }^{24}$ tal como o Cândido de Voltaire. "Podemos julgar Cândido Neves como bem entendermos, mas teremos sempre que buscar algum valor externo à situação, algum princípio além, fora desse querer viver irracional. Sua candidez reside justamente no fato de não buscar justificativa para a vida." 25

Machado de Assis ainda parece jogar com o mesmo artifício para empurrar o leitor a algumas considerações e julgamentos: por exemplo, o sobrenome Neves e o nome de sua esposa Clara nos remetem a conjecturar as cores de suas peles, invertendo o sentido, e suas condições sociais. O fato de ela ser órfã e de Cândido Neves ser caipora, além de ambos sofrerem com a pobreza e estarem esperando um filho sem condições de criá-lo, nos permite situar as razões para o protagonista escolher pegar escravos fugidos como ofício.

Não seria nobre, mas por ser instrumento da força com que se mantêm a lei e a propriedade, trazia esta outra nobreza implícita das ações reivindicadoras. Ninguém se metia em tal ofício por desfastio ou estudo; a pobreza, a necessidade de uma achega, a inaptidão para outros trabalhos, o acaso, e alguma vez o gosto de servir também, ainda que por outra via, davam o impulso ao homem que se sentia bastante rijo para pôr ordem à desordem. ${ }^{26}$

Cândido Neves encontra nesse ofício a possibilidade de se manter financeiramente melhor do que nos vários outros melhores e piores que tentou, e soma-se ainda um simples defeito: "não aguentava emprego nem ofício, carecia de estabilidade". Arrastado pelo acaso, resta a ele, "jogando com

${ }^{23}$ ALMEIDA, O delírio de Brás Cubas: síntese do pensamento filosófico machadiano, p. 23.

${ }^{24}$ ALMEIDA, O imaginário trágico de Machado de Assis, p. 206.

25 Idem.

${ }^{26}$ ASSIS, Pai contra mãe, Relíquias de casa velha, p. 50. 
as convenções, agarrando-se ao desejo de conservação, atribuindo sentido de acordo com a conveniência", viver em meio às circunstâncias.

Mas as circunstâncias depois do nascimento de seu filho dificultaram muito a situação, a crescente dificuldade em capturar escravos fugidos devido à maior escassez e concorrência fez Cândido Neves não encontrar mais meios para comprar comida. As chances de seu filho vingar eram mínimas.

Nesse contexto, podemos situar Mônica, que etimologicamente remete a "solidão" por origem grega (monikós), ou a "conselheira" por origem latina (monere). É justamente isso que caracteriza a personagem no conto, seus conselhos expressavam sua solidão. Vivia somente com sua sobrinha órfã, que não lhe deu ouvidos quando falou sobre os "filhos possíveis":

- Vocês, se tiverem um filho, morrem de fome, disse a tia à sobrinha. ${ }^{27}$

Se tivessem seguido o que ela falara, não haveriam chegado a uma situação tão complicada. Mônica chegara ainda a aconselhar que Cândido Neves procurasse algo mais certo, um novo emprego. Mas nem uma coisa nem outra: tiveram um filho; - Clara continuou a coser mais e Mônica a ajudar para tentar manter alguma renda em meio à esporadicidade dos ganhos das capturas de Cândido Neves. Então, outro conselho foi dado depois da realização de sua profecia anterior: "levar a criança que nascesse à Roda dos enjeitados". 28

No entanto, Cândido nunca fez o que Mônica aconselhara, mas este último quase seguiu a contragosto. Em ato de desespero, procurou pelo anúncio de melhor recompensa. Teve como único sucesso o relato de um farmacêutico que lhe disse que uma pessoa parecida com as informações dadas tinha passado lá e comprou "uma onça de qualquer droga, três dias antes". ${ }^{29}$ Era muito pouco e naquele momento pareceu nada.

Ora, temos aqui tudo para uma lição de moral, tudo para justificar o que é o certo e o errado. Cândido Neves não teria agido ingenuamente tal como a etimologia de seu nome sugere, Clara viveria marcada por ter enjeitado o filho, e Mônica teria finalmente visto alguém aceitar seu conselho, isto é, não teria falado sozinha.

Entretanto, quando finalmente o pai decide levar o filho, eis que o acaso lança o destino:

\footnotetext{
${ }^{27}$ Idem, p. 51.

${ }^{28}$ Idem, p. 54.

${ }^{29}$ Idem, p. 56.
} 
Que pensasse mais de uma vez em voltar para casa com ele, é certo; não menos certo é que o agasalhava muito, que o beijava, que cobria o rosto para preservá-lo do sereno. Ao entrar na Rua da Guarda Velha, Cândido Neves começou a afrouxar o passo.

- Hei de entregá-lo o mais tarde que puder, murmurou ele.

Mas não sendo a rua infinita ou sequer longa, viria a acabá-la; foi então que lhe ocorreu entrar por um dos becos que ligavam aquela à Rua da Ajuda. Chegou ao fim do beco e, indo a dobrar à direita, na direção do Largo da Ajuda, viu do lado oposto um vulto de mulher; era a mulata fugida. Não dou aqui a comoção de Cândido Neves por não podê-lo fazer com a intensidade real. Um adjetivo basta; digamos enorme. Descendo a mulher, desceu ele também; a poucos passos estava a farmácia onde obtivera a informação, que referi acima. Entrou, achou o farmacêutico, pediu-lhe a fineza de guardar a criança por um instante; viria buscá-la sem falta.

- Mas...

Cândido Neves não lhe deu tempo de dizer nada; saiu rápido, atravessou a rua, até ao ponto em que pudesse pegar a mulher sem dar alarma. No extremo da rua, quando ela ia a descer a de S. José, Cândido Neves aproximou-se dela. Era a mesma, era a mulata fujona. - Arminda! bradou, conforme a nomeava o anúncio. ${ }^{30}$

Este é o ponto em que o cru da realidade dá à vista o trágico sem revestimentos do pensamento paranoico, construtor e salvador: tal como sua esposa estivera nos últimos meses, Arminda estava grávida e agora desesperada tal como ele havia poucos instantes:

- Estou grávida, meu senhor! - exclamou. - Se Vossa Senhoria tem algum filho, peço-lhe por amor dele que me solte; eu serei tua escrava, vou servilo pelo tempo que quiser. Me solte, meu senhor moço!

- Siga! - repetiu Cândido Neves.

- Me solte!

- Não quero demoras; siga! ${ }^{1}$

Apelando, ou não, Arminda disse ainda que seria açoitada, alegação que teve como resposta: “- Você é que tem culpa. Quem lhe manda fazer filhos e

${ }^{30}$ Idem, p. 57.

${ }^{31}$ Idem, p. 57-58. 
fugir depois?". ${ }^{2}$ A luta para não ser resgatada rendeu uma consequência dolorosa:

O fruto de algum tempo entrou sem vida neste mundo, entre os gemidos da mãe e os gestos de desespero do dono. Cândido Neves viu todo esse espetáculo. Não sabia que horas eram. Quaisquer que fossem, urgia correr à Rua da Ajuda, e foi o que ele fez sem querer conhecer as consequências do desastre. ${ }^{33}$

Diante desse desfecho, surpreende o diálogo entre Clara e sua tia Mônica meses antes, quando da notícia do filho por vir:

- Vocês verão a triste vida - suspirava ela.

- Mas as outras crianças não nascem também? - perguntou Clara.

- Nascem, e acham sempre alguma cousa certa que comer, ainda que pouco...

- Certa como?

- Certa, um emprego, um ofício, uma ocupação, mas em que é que o pai dessa infeliz criatura que aí vem gasta o tempo? ${ }^{34}$

O pai da criatura viva não se cabia de alegria, mesmo que por sua causa a fuga da desesperada mãe a tenha feito perder o filho. "- Nem todas as crianças vingam, bateu-lhe o coração". ${ }^{5}$ Esta constatação mostra o desaviso do otimismo como o de Clara, mas o ocorrido mostra também que o pessimismo não tem base metafísica para se sustentar: o acaso não tem critério para determinar os acontecimentos, é indiferente ao sentido que o homem procura dar à existência. "Cândido Neves, beijando o filho, entre lágrimas, verdadeiras, abençoava a fuga e não se lhe dava do aborto." 36

A questão central, portanto, seria essa vontade de viver, essa fúria, essa adesão à vida, essa alegria existencial que, mesmo diante de uma realidade desagradável, não cessa de se manifestar. E embora caibam críticas e ressalvas quanto às circunstâncias sociais que ensejam esses dramas, é de se notar a alegria de viver de Cândido Neves, mesmo com todas as razões e disposições a contrario. ${ }^{37}$

\footnotetext{
${ }^{32}$ Idem, p. 58.

${ }^{33}$ Ibidem.

${ }^{34}$ Idem, p. 52.

${ }^{35}$ Idem, p. 59.

${ }^{36}$ Ibidem.

${ }^{37}$ ALMEIDA, O imaginário trágico em Machado de Assis: elementos para uma pedagogia da escolha, p. 205
} 
Neste ponto, temos um exemplo que contrasta bem a diferença citada entre a escolha trágica e a resignação cética; na perspectiva trágica vive-se com o júbilo de quem afirma a vida com tudo o que ela oferece, integralmente - sofremos em momentos de dor, alegramo-nos em momentos de felicidade.

A vontade de viver assegura à vida o valor maior, embora não valha nada (fora da própria vida) - esse absurdo não conduz, em Machado, ao pessimismo, mas ao jogo, às estratégias do brilho social, do espetáculo da vida. $^{38}$

Não podemos deixar de notar que nesse conto o espetáculo é horroroso, mas ainda um espetáculo. Os atos de Cândido Neves moralmente parecem repreensíveis, mas o acaso não tem nada com isso. Não há lição de moral, há somente uma lição a se aprender: algo que não se pode ensinar diretamente, algo que só é possível ver porque não se exprime com a razão, a saber, a visão do trágico.

É trágico o que deixa mudo todo o discurso, o que se furta a toda tentativa de interpretação: particularmente a interpretação racional (ordem das causas e dos fins), religiosa ou moral (ordem das justificações de toda natureza). O trágico então é o silêncio. ${ }^{39}$

Como, então, pôr a falar o que só se pode silenciar? Eis o desafio e o caráter pedagógico que se podem depreender da obra machadiana à luz da filosofia trágica. "Nenhuma intenção pedagógica de transformação, mas de aprovação." 40 Como o filósofo terrorista descrito por Rosset, ${ }^{41}$ vemos Machado de Assis fazer falar o trágico, ora troçando da filosofia, ora narrando diferentes variações do comportamento humano:

As formas várias que agitam o homem - seja amor, vaidade, fome ou melancolia - são variações de um mal, mal que aparece indefinido, vestido de arlequim, indiferente à dor e ao prazer, que o morde física e mentalmente, revelando a impossibilidade tanto de escapar da morte e da debilidade (flagelo físico) quanto de compreendê-los (rebeldia do pensamento). A impossibilidade de interpretar esse mal, que é a própria

\footnotetext{
${ }^{38}$ ALMEIDA, O mundo, os homens e suas obras: filosofia trágica e pedagogia da escolha, p. 21.

${ }^{39}$ ROSSET, Lógica do pior, p. 65.

${ }^{40}$ ALMEIDA, O imaginário trágico de Machado de Assis: elementos para uma pedagogia da escolha, p. 209.

${ }^{41}$ ROSSET, Lógica do pior. Ver o primeiro capítulo: "Do terrorismo em filosofia”.
} 
existência (fatalidade das coisas), traveste-se, no entanto, em busca de felicidade (ilusão). ${ }^{42}$

O pensador trágico com sua intenção terrorista mostra os males e afirma o pior possível - que é o nada de sentido da existência -, motivado por uma piedade trágica, qual seja: verter venenos em remédios para maior receptividade dos males. Munido contra qualquer mal, o homem pode finalmente aprovar a vida incondicionalmente.

Neste sentido, a filosofia trágica é uma "farmácia”, uma arte dos venenos que consiste em verter no espírito daquele que escuta um veneno mais violento que os males que presentemente o afligem. Assim Nietzsche pretendia avaliar os homens e as filosofias na medida da violência dos venenos que eles são suscetíveis de assimilar: o sinal da saúde sendo a "boa" receptividade ao veneno. ${ }^{43}$

Carregando nas tintas, podemos dizer que a filosofia trágica é uma farmácia na Rua da Ajuda que leva até o Largo da Ajuda (onde se encenam a vida e a morte). A farmácia não está na rua principal (Rua da Guarda Velha), a via mais usada; é preciso passar por uns becos. Há aqueles que desaprovam o espetáculo da vida porque não tomam os venenos vertidos em remédio desta farmácia. Os remédios, doados por piedade do farmacêutico, preparam o espectador para apreciar os fatos encenados na peça.

O que decorre da visão do trágico: ou negamos o acaso criando algo, que é nada, para acreditar, ou aprovamos o acaso que põe todos os acontecimentos na mesma superfície do não modificável:

Mais abstratamente: o ser não pode mudar de natureza, na medida em que ele não constitui uma "natureza". Se o ser é, não natureza, mas acaso, ele escapa necessariamente de toda a alteração de natureza - donde toda a inanidade de toda ação (sobre a "natureza"). ${ }^{44}$

Se agir no sentido de mudar a natureza das coisas é impossível, resta viver em meio às convenções. Se tudo é acaso e sem sentido, de modo que nada é passível de justificativa; se tudo é espetáculo, onde se vê uma corrida desenfreada para a morte; se tudo é ilusão, que nos dispomos a repelir ou a

\footnotetext{
${ }^{42}$ ALMEIDA, O delírio de Brás Cubas: síntese do pensamento filosófico machadiano, p. 26.

${ }^{43}$ ROSSET, Lógica do pior, p. 28.

${ }^{44}$ Idem, p. 50.
} 
buscar; então, felicidade e sofrimento são consequências dos lances de sorte. As tentativas de interpretações de tais lances revelam uma negação da vida, uma crença fundamentada em nada, um modo de interpretação que nada explica sobre o sentido do que é, porque nada há para interpretar.

Por conseguinte, restam a fazer três escolhas existenciais:

[...] escolhas de ordem pedagógica, pois modificam o próprio modo como a vida é vivida: ou se escolhe recusá-la integralmente, o que significa a opção pelo suicídio. Ou se escolhe aprová-la provisoriamente, sob determinadas condições, o que significa opção pela ilusão; ou se escolhe aprová-la integralmente, escolha trágica, que aceita a existência como se apresenta, com sua efemeridade, instabilidade, insignificância, com seus artifícios, suas possibilidades, suas convenções, enfim, o que é dado a viver. E essa aprovação é já expressão da alegria de viver, do gozo de se saber, apesar de provisório, vivo. Capaz de, mesmo diante da pior realidade possível, ratificar o desejo de viver. ${ }^{45}$

Por fim, podemos concluir o seguinte: a riqueza da obra de Machado de Assis que se fundamenta na expressão do trágico nos permite fazer vários outros tipos de leituras. Leituras não trágicas que procuram encontrar elementos para racionalizar uma ordem ante o acaso, o nada e a convenção as três principais raízes da linha de força da filosofia trágica. Esta variedade não legitima o pensamento não trágico, mas permite a compreensão da distinção entre o posicionamento que aprova e o que desaprova a vida; em outras palavras, permite reconhecer leituras fundamentadas por filosofias que condicionam o sentido da vida em contraposição à única leitura que aprova a vida incondicionalmente. Em "Pai contra mãe" temos um exemplo singular disso por meio de um protagonista que expressa uma aprovação da vida sem necessidade de explicações dos fatos e justificações dos atos.

45 ALMEIDA, O imaginário trágico de Machado de Assis: elementos para uma pedagogia da escolha, p. 204. 


\section{Referências}

ALMEIDA, Rogério de. Aprendizagem de desaprender: Machado de Assis e a pedagogia da escolha.Educ. Pesqui., São Paulo, v. 39, n. 4, p. 1001-1016, out./dez. 2013. O delírio de Brás Cubas: síntese do pensamento filosófico machadiano. Machado de Assis em Linha, ano 3, n. 6, p. 15-28, dez. 2010.

. O imaginário trágico de Machado de Assis: elementos para uma pedagogia da escolha. São Paulo: Képos, 2015.

. O mundo, os homens e suas obras: filosofia trágica e pedagogia da escolha. Tese de livre-docência. Faculdade de Educação, Universidade de São Paulo, São Paulo, 2015.

ASSIS, Machado de. Relíquias de casa velha. Edições críticas de obras de Machado de Assis. Rio de Janeiro: Civilização Brasileira, v. 11, 1975.

PORCHAT PEREIRA, Oswaldo. Rumo ao ceticismo. São Paulo: Unesp, 2006.

ROSSET, Clément. Lógica do pior. Rio de Janeiro: Tempo e Espaço, 1989.

. O princípio de crueldade. São Paulo: Rocco, 2002.

LEANDRO SANTOS RESENDE é bacharel e licenciado em Filosofia pela Faculdade de Filosofia, Letras e Ciências Humanas da Universidade de São Paulo (FFLCH) e mestrando em Educação pelo Programa de Pós-Graduação da Faculdade de Educação da Universidade de São Paulo (FEUSP), onde desenvolve, com bolsa do CNPq, o projeto de pesquisa $O$ cômico e o conhecimento: o entendimento do riso trágico como mediação no processo de (auto)formação. Participa do GEIFEC (Grupo de Estudos sobre Itinerários de Formação em Educação e Cultura). E-mail: leandro.resende@usp.br.

Recebido: 18.04 .16

Aprovado: 15.06 .16 